\title{
Shifting Informal Actors of Traditional Miners into Formal: Case Study Pasaman, West Sumatera
}

\author{
Benny Oktis Yanurwenda \\ Bukittinggi Tax Office \\ Directorate General of Taxes \\ Bukittinggi, Indonesia \\ y anurwenda@gmail.com
}

\begin{abstract}
The paper examines the issue about traditional miners as a part of complicated problems in mining sector. There are the potential conflict in operational level caused by granting mining license to the mining sites where traditional miners exploiting the resources. It is the needs to reduce the conflict potential and as part of solution, government should attempt shifting the informal activities of the miners into formal. To apply this, the form of business entity is important to cover the miners activities. There are two possible forms of business may be apply theoretically, Village Owned Enterprise and Cooperative.
\end{abstract}

Keywords—-traditional miner, conflict, legal entity

\section{INTRODUCTION}

Article 33 paragraph (3) the Constitution of Republic of Indonesia 1945 stated that "The land, the water, and the natural riches contained therein shall be controlled by the State and exploited to the greatest benefit of the people. The article became the basis for Minerals and Coal Law which gives the government the right to manage mining sector in Indonesia.

Unfortunately, mining sector faces complicated problems in operational stage. In many mining sites, traditional miners have been exploiting them for years before the government gives the permit for certain companies. When new company comes to the sites, traditional miners will give very hard rejection. The situation becomes more complicated because the mining site is considered as customary land by local people so that they acclaim having the right to utilize it.

In Pasaman West Sumatera, gold mining permit given to PT IJM had triggered the conflict between the company and local people. There are many related issues in the conflict, but one of the important factors that should be considered is that there are traditional miners exploiting the gold surrounding conflict location before the permit released.

\section{THE ECONOMY OF PASAMAN}

\section{A. General Economy Background}

Pasaman is one of the regency in West Sumatera. The regency is one of regency traversed by equator. It is located on the northern part of province, bordered by province North Sumatera and Riau.

Based on Bureau of Central Statistics, the economic structure is dominated by sector of farming, forestry, and fishery. Its portion in the economic share is around 51 percent. If it compares to other region in West Sumatera, economy of Pasaman is relatively is not satisfying enough because in last five years, Regional Income per capita and economic growth are always below the average. The percentage of poor people in Pasaman is also higer than province's average.

Inhabitants of Pasaman in 2016 is 272.804 people. From this number, the workforce is around 67 percent of population. Only five percent of labor force is in unemployment. Majority of worker's education is maximum Junior High School so there is the problem in labor skills. There is also lack of work opportunity in Pasaman so many of the workforces have been looking for job to outside Pasaman.[1]

Beside the problem in workforce, Pasaman also faces problems in infrastructure. The road is still limited with ratio 0,26 kilometres per 1 kilometre square. The road with good quality is also only around 54 percent. With the condition, Pasaman has big challenges to increase the economic productivity. Therefore, local government should invite large investments to invest there.

\section{B. The Potential of Mining}

Based on the research of Hotma Simangunsong, Pasaman has potential in mining. It has 12 locations of gold, 2 locations of iron, and 1 location of galena. Unfortunately, the sites are mostly located in protected forest. Moreover, the risks of mining activities are also high so it is important to attract investors. [2]

Research of Statistical Bureau indicated that Pasaman has the economic potential in mining. Based on Location Quotient coefficient, analysis describing the role of economic sector in particular region by comparing of its role in greater region, mining sector is one of its champion sectors. The sector growth had been in the middle among all sectors in Pasaman. The sector also had absorbed 1.767 labours.[3]

Based on Ministry of Energy and Mineral Resources, government had also given 25 mining licenses in Pasaman area. However, there are only few companies that actively perform mining operations. They are still dominated by lowmiddle enterprises. In 2016, 840 entities had the business in the sector and 99 percent is low-middle enterprises. 
Even though there is great potential in mining, its utilization is still limited. Mining Regional Income share is around 2.1 percent of Pasaman regional income. Compared to other municipals in West Sumatera that have huge mining potential, the proportion is relatively low. For example, mining proportion of Dharmasraya is 8.12 percent of regional income[4], that of Sijunjung is 14.2 percent[5]. Therefore, Pasaman is still deemed as low-income regency in West Sumatera. Among 19 regency and municipal, Pasaman is second lowest regency in term of Regional Income per capita. Therefore, it is challenging about how to utilize the potential and give the impact to increase people's income.

\section{ThE CONFLICT BETWEENCOMPANy AND LOCAL PEOPLE}

\section{A. Exploitation of the Mining by Traditional Miners}

Exploitation of gold mining sites by local people has been occurred for many years. Pasaman has a long history as a mining relic of Dutch colonist. People currently exploit traditionally and it has encouraged more people to join the activities.[6]

In 2009, government had made the regulation in mining become stricter by enactment of Minerals and Coal Act. By the act, government has the authority to manage the giving of mining license to particular parties. People should apply to government if they want to perform activities in mining sectors. As a consequence, traditional miners' activities should be terminated.

However, in reality, traditional miners' activities have still occurred. In many official inspections, it had been found numerous heavy equipments that indicated utilized for mining operations. Government has seemed unable to effectively stop traditional miner activities even though based on law perspective, they are illegal.

Even though there are positive impacts of those activities, there are many problems caused by them. In environment is sue, the activities utilize many hazardous materials, such as mercury. Ecosystem protection from hazardous wastes cannot be ascertained because the miners cannot be controlled by authorized institution.

Moreover, the activities also have problems in labor safety. They usually do not have working standard. Even though they make it, there is no significant effort to comply with it. Labors are not mostly covered by working security protection. The conditions make the workers are placed in fragile situation. Unfortunately, there is no official report that record work accidents on the activities. Therefore, even though the activities brought economic impacts to the people, the government should initiate the actions to reduce them.

The activities of traditional miners may be classified as underground economy. According to Smith, underground economy is production of goods and services, legal or illegal, which is missed by the calculation of Gross Domestic Product. There are four classification of underground economy:

- The illegal economy

- The unreported economy

- The unrecorded economy

- The informal economy[7]
The activities of the miners may be classified as the illegal economy because the operations are not aligned with the prevailing law. However, in the surrounding, the activities may not be recognized as "bad" activities. The contradiction may cause inconsistency on applying the law.

\section{B. The Giving of Mining License to the Company}

There is acknowledged that the potential of mining in Pasaman, especially Duo Koto District, is huge. However, to identify how big that potential, PT IJM should perform further research and exploration stage. Based on the research, it had been expected that the site has gold potential as huge as 110.000 ounces. Each meter cubic may produce a gram of gold with purity level $97-98$ percent.

If the potential is matched with business feasibility, company should apply to be given mining license. To get mining license on that area, PT IJM should make environment analysis to evaluate the impact of mining activities to environment. As a result, in 2017, PT IJM had been given mining license from Governor of West Sumatera number 544/274/2017. Based on the license, PT IJM had been granted the right to exploit the mining on the area covering 2.408 hectares. It is placed on production forest area. The license has been valid since October 2017 until December 2036.

PT IJM is subsidiary of PT SIP. PT SIP itself has specialty in trading and electronic services. PT SIP had taken over PT IJM from its previous owner worth USD 3 million.

PT SIP's stocks are also traded in stock exchange with code TMPI. Acquisition of PT IJM and the potential of managing mining sites have given significant impact to stock transactions. Investors had optimistic perspective to company's prospect so it drove the price increase.

\section{Responses of Local People to License Granting}

Generally people surrounding the mining sites have two separate responses related to mining license grant to company. One party gives the support to the license because it will open work opportunities to local people. Other party rejects the license for several reasons. The arguments relate to several issues, such as: environment, human right, and government administration. Ho wever, people that against the company more articulate on expressing the aspiration in many ways.

Even though the arguments are covered by some matters, it can be inferred that the economic issue takes significant concern from the protesters. One of their demands is to withdraw the license. To express their demands, protesters have arranged many demonstrations on many places, such as: mining sites, regent office, and governor office. Some demonstrations triggered for violence, such as burning cars and company's office.

In economic perspective, traditional miners may be threatened by new company possessing mining license. The new company comes with modern equipments, high skills, and huge investment. The company may also be expected closing the previous miners to the location under its possessing. As a result, the miners will have expectation that their income will be affected of the company's operations. Therefore, they give hard reaction for company's operation. 


\section{Possible W Ays To Reduce The CONFlict}

There are contradictory positions between government and traditional miners. Government would like to eliminate illegal activities on mining sites and encourage investors to invest there. On the other hand, the miners wish for continuing their operation. These positions are not easy to find position that can be accepted by all parties.

Moreover, government efforts to terminate the activities seemed not effective. It is likely that social and politic issues are highly influenced government actions. Hard approach may cause the government to lose people's support and increase social tension in that area. If the government gives the license for particular company and there is no solution for the miners, in the future, they probably will disturb the legal mining activities and affect investment climate. Therefore, government should consider comprehensive aspects before taking decision to the is sue.

As a beginning, the government should recognize the existence of the miners even though their activities cannot be justified. It is the fundamental for the rest activities. Government should identify mining sites in which local people involved in illegal mining activities. Then, government should consider which solutions can be applied to them.

Generally, there are two parties involved in mining sites, capital owners and the miners. Each party has unique characteristics that should be considered. Capital owners generally have the role to supply the equipments needed by the traditional miners. On the other hand, the miners perform mining activities.

Between those two parties, the miners are the most vulnerable one of to face the impact if the change in the structure of mining activities occurs. They may lose their jobs when the mining company operates because they usually have low productivity. Therefore, it is reasonable if they will give hard reaction to the change.

On the other hand, capital owners may have ability to adapt to the situation. They may transform the business to be in line with the new surroundings. For example, they may become the supplier of mining company or provide the needs of the company's workers.

However, they may lose privilege position caused by the access of mining sites. As a result, they may enjoy lower profitability than before. On this perspective, they may support hard reaction to the mining company. Furthermore, it is very possible that they initiate the reaction to the company.

Based on abovementioned conditions, government may seriously consider aspirations of the miners. Their limited skills may cause lack of opportunities. Therefore, if government intends to make make mining activities become legally operated, that may accomodate the miners optimally.

Based on the level of technology, mining activities vary from low level into high level. When the activities need high technology, it will absorb capital entensively. In the situation, the participation of investors is required. Otherwise, if the activities only require simple one, local people may be involved.

In order to invite participation of local people, legal entity may be needed. It is important to minimize situation where the opportunity is only dominated by a group of people. It may create moral hazard or corruption. Moreover, it is also important to eliminate the weakness of illegal activities, such as: work safety problems and protecting environment.

However, even though the miners' activities form in legal entity, the support of government is essential. The entity may not be let to be fully controlled by the local people because their capabilities in running business are still limited. Moreover, it is also important to minimize conflict potential and to make sure that the entity's activities are in line with prevailing laws. This condition provides the instruments for government to give directions and evaluate whether the results are in line with the intention.

The entity form may accommodate above conditions. Based on regulation, there are several forms of business entity. However, the entity forms that may accommodate the local people's interests according to Indonesian law may be Village Owned Enterprise and Cooperative.

\section{A. Village Owned Enterprise}

In the Minister of Village and Development of Disadvantaged Regions Regulation, Village owned Enterprise is defined as business entity whose capital, partially or entirely, possessed by Village through direct investment from separated Village's wealth, in order to manage asset, services, and other business for maximizing village's residents. It also regulates that the Village Owned Company may be given access to manage resources in its area.[8] It indicates that the village government may have opportunity to increase local people's welfare by facilitating them involved in business. It may be performed by utilizing economic potential in there. It may be formed in natural resources, specialized skills, or other economic potentials.

The form of Village Owned Enterprise may give several advantages. Its form provides solid management and firm decision making process because it gives clarity on the management structure. Moreover, the business entity has close relationship with local people so it will have high supervision. Therefore, the form will acco mmodate the needs of village's residents optimally.

On the other hand, there are several weaknesses that should be addressed. Village's residents that have the ability to manage the business may be limited or sometimes may not be available. In many situations, the roles of business manager are really crucial so many parties are competing to take the position. Moreover, the role of Village government are very significant so if there is weak supervision, the potential of corruption

The mining activities are relatively complicated so the structure of business should have clarity in making decision and it is operated professionally. In many circumstances, local residents have limited ability to manage the mining business. Therefore, it seems that this form may be applied on that condition. This form also may give government to play important role.

\section{B. Cooperative}

In the Cooperative Law, Cooperative is defined as legal entity founded by persons or Cooperatives, with separation of members' wealth as capital to run business, to fulfill shared aspirations and needs in economy, social, and 
cultures, in accordance with Cooperative's values and principles [9]. The point issue is that Cooperative should accommodate shared aspirations and needs. It indicates that Cooperative controls by all members and no particular party may be able to dominate it.

Cooperative treats all members in similar position. This structure will make sure that Cooperative will concern about all aspirations. Therefore, it can be inferred that Cooperative form may increase the village's wealth optimally.

However, the complicated of mining business may cause the equal position of members make decision making will be harder. On complicated situation, me mbers may have various points of view that cannot be accommodated comprehensively. Therefore, this condition may be as an obstacle to the growth of business.

Based on above conditions, it can be inferred that in simple business, Cooperative form may give better welfare for local people. However, the entity may be encouraged to take crucial decision to expand its business. Therefore, government may reduce its weakness by taking supporting role to give more opportunity to the business growth.

\section{CONCLUSION}

It is the fact that many mining sites are exploited by traditional miners. The traditional miners are usually local people of surrounding area and they exploit the sites in illegal way. However, the enforcement is relatively weak because many residents rely on the activities as their income.

Unfortunately, government usually does not consider the existence of traditional miners. On the other hand, government also cannot prevent the activities effectively. If particular mining sites are not granted mining license, it will deemed as "clear" sites so the mining license may be released even though there are local people exploiting the area. Therefore, it may cause the conflict between the miners and the company who is granted the license.

To minimize the conflict potential, government may consider the miners' existence before taking decisions. One of possible solution to evade the conflict is that government may involve the miners to join in legal activities. Therefore, government may attempt to shift the miners' activities from informal into formal.

To shift the miners, the form of business entity to them is needed. There are several forms of business entity that may be applied. Theoretically, the most proper forms that may be applied are Village Owned Enterprise and Cooperative. If the local people still have limited ability to run business, Village Owned Enterprise may be suitable because government may have control. On the other hand, if local people may have sufficient capacity, Cooperative may be a right form.

\section{REFERENCES}

[1] Central Bureau of Statistics of Pasaman, Pasaman Regency in Figures 2017 (Kabupaten Pasaman dalam Angka 2017), 2017.

[2] H. Simangunsong, "Inventory and Evaluation of Metal Minerals in Pasaman Regency and West Pasaman Regency Province West Sumatera (Inventarisasi dan Evaluasi Mineral Logam di Daerah Kabupaten Pasaman dan Kabupaten Pasaman Barat Propinsi Sumatera Barat), unpublished.

[3] Central Bureau of Statistics of Pasaman, "Economic Portrait the Result of Complete Economic Census 2016 Economic Potential of
Pasaman Regency (Potret Ekonomi Hasil Pencacahan Lengkap Sensus Ekonomi 2016 Potensi Ekonomi Kabupaten Pasaman), 2017.

[4] Central Bureau of Statistics of Dharmasraya, Dharmasraya Regency in Figures 2017 (Kabupaten Dharmasraya dalam Angka 2017), 2017.

[5] Central Bureau of Statistics of Sijunjung, Gross Regional Domestic Bruto of Sijunjung Regency by Industry 2012-2016 (Produk Domestik Regional Bruto Kabupaten Sijunjung menurut Lapangan Usaha 2012-2016), 2017.

[6] H.Z. Abidin and B.H. Harahap, "Indication of Low-Sulphide Epithermal Gold Mineralization in Bonjol District Pasaman Regency West Sumatera (Indikasi Mineralisasi Epitermal Emas Bersulfida Rendah di Wilayah Kecamatan Bonjol, Kabupaten Pasaman Sumatera Barat), in Journal of Indonesian Geology (Jurnal Geologi Indonesia), Vol. 2 No. 1, March 2007, pp.55-67.

[7] S.J.A Samuda, Underground Economy in Indonesia, in Economics Monetary and Banking Bulletin (Buletin Ekonomi Moneter dan Perbankan), Volume 19 No. 1, July 2016, pp. 39-56

[8] Minister of Village and Development of Disadvantages Regions Regulation Number 4 Year 2015 concerning Establishment, Management, Control, and Dissolution Village Owned Enterprise (Peraturan Menteri Desa dan Pembangunan Daerah Tertinggal Nomor 4 Tahun 2015 tentang Pendirian Pengelolaan, Pengurusan, dan Pembubaran Badan Usaha Milik Desa).

[9] Law Number 17 Year 2012 concerning Cooperative (Undang-Undang Nomor 17 Tahun 2012 tentang Perkoperasian). 